\title{
Effects of Azotobacter chroococcum on Barley Seed Germination and Seedling Development
}

\author{
By S. H. T. HARPER AND J. M. LYNCH \\ Agricultural Research Council Letcombe Laboratory, Wantage, Oxfordshire OX12 9JT
}

(Received 17 August 1978)

\begin{abstract}
When cells or the culture filtrate of Azotobacter chroococcum grown on a medium without a source of fixed nitrogen were added to barley seeds, they sometimes stimulated the extension of seedling roots. The stimulation appeared to be due to a bacterial metabolite as the cells used were non-viable (due to a decrease in $\mathrm{pH}$ of the growth medium). There was no evidence that 3-indoleacetic acid or gibberellic acid, which were produced by the bacterium, were involved in the stimulation. When the bacterium was grown on a medium containing nitrate, the cells, but not the culture filtrate, always inhibited germination and the extension of seedling roots. This inhibition of germination appears to be due to competition between viable bacteria and seed for available oxygen.
\end{abstract}

\section{INTRODUCTION}

The inoculation of seeds or seedlings with micro-organisms has been adopted as a method of modifying microbial populations around crop plants to promote both development and yield. Azotobacter chroococcum was originally used as a seed inoculant because it was thought that its fixation of dinitrogen would provide a significant input to the nitrogen economy of plants (Cooper, 1959). The reported increases in yield after seed inoculation, which have rarely exceeded $10 \%$ in cereals, now seem unlikely to have resulted from improved mineral nutrition since the greatest effects of inoculation have been reported in fertile soils (Brown, 1974). Furthermore, nitrogen fixation is limited by the availability of carbohydrate (Postgate, 1974), which in the rhizosphere is provided by root exudates. The quantity of root exudate released by roots of temperate cereals is unlikely to supply enough substrate to stimulate nitrogen fixation in the rhizosphere sufficiently to contribute significantly to the total crop requirement, even when Azotobacter spp. are the only microbial species in the rhizosphere (Barber \& Lynch, 1977).

The stimulation of seedling development by bacteria has also been attributed to the production of biologically active compounds (Brown, 1974; Rubenchik, 1963; Mishustin, 1970); A. chroococcum produces substances which behave like 3-indoleacetic acid (IAA) and gibberellic acid $\left(\mathrm{GA}_{3}\right)$ in bioassays. The highest concentrations of IAA-like and $\mathrm{GA}_{3}$ like substances detected in culture media have been $11 \mu \mathrm{g} \mathrm{ml}^{-1}$ (Brakel \& Hilger, 1965) and $20 \mu \mathrm{g} \mathrm{ml}^{-1}$ (Vancura, 1961), respectively. However, the precise chemical nature of these substances has not yet been identified. Furthermore, although these compounds are found in culture media, particularly when immediate metabolic precursors are added, their production in the rhizosphere remains to be demonstrated.

The major limitation to a more widespread use of seed inoculation has generally been the variability in effects in both field and laboratory studies (Mishustin \& Shilnikova, 1969; Brown, 1974). Differences in inoculum concentration and physiology between inoculation trials may be one source of variability. The effects of Azotobacter on early seedling development, the stage most likely to be influenced by inoculation (Rovira, 1965), can, for example, 
vary with inoculum concentration (Siegel \& Schmidt, 1966) and age of the culture (Brown et al., 1962).

Tomato, which is particularly susceptible to the effects of growth regulators, has often been used as a test plant but the results may not be applicable to cereals. Barley is a suitable cereal for study because the processes involved in germination have been studied in detail (Macleod, 1969). We have therefore used barley to study the effects of $A$. chroococcum on seed germination and seedling growth.

\section{METHODS}

Growth of inocula. Azotobacter chroococcum strain A6 (Patel, 1969) was cultured on two media. The nitrogen-free medium was that described by Dalton \& Postgate (1969), but with sucrose, which was found to support better growth than mannitol, as the carbon source. This medium contained (per litre): sucrose, $10 \mathrm{~g} ; \mathrm{K}_{2} \mathrm{HPO}_{4}, 0.64 \mathrm{~g} ; \mathrm{KH}_{2} \mathrm{PO}_{4}, 0.16 \mathrm{~g} ; \mathrm{NaCl}, 0.2 \mathrm{~g} ; \mathrm{MgSO}_{4} .7 \mathrm{H}_{2} \mathrm{O}, 0.2 \mathrm{~g} ; \mathrm{CaCl}_{2}, 0.1 \mathrm{~g} ;$ nitrilotriacetic acid, $0.1 \mathrm{~g} ; \mathrm{H}_{3} \mathrm{BO}_{3}, 2.9 \mathrm{mg} ; \mathrm{FeSO}_{4} .7 \mathrm{H}_{2} \mathrm{O}, 2.5 \mathrm{mg} ; \mathrm{Na}_{2} \mathrm{MoO}_{4} .2 \mathrm{H}_{2} \mathrm{O}, 2.5 \mathrm{mg} ; \mathrm{CoSO}_{4}, 1.2 \mathrm{mg} ; \mathrm{ZnSO}_{4} .7 \mathrm{H}_{2} \mathrm{O}$, $1.2 \mathrm{mg} ; \mathrm{CuSO}_{4} .7 \mathrm{H}_{2} \mathrm{O}, 0.1 \mathrm{mg} ; \mathrm{MnCl}_{2} .4 \mathrm{H}_{2} \mathrm{O}, 0.09 \mathrm{mg}$. This medium solidified with $1.5 \%$ (w/v) agar was used to maintain the culture. The medium containing nitrate was that which is normally used for the growth of plants, but amended with sucrose and additional phosphate buffer for the culture of A. chroococcum. It contained (per litre): sucrose, $10 \mathrm{~g} ; \mathrm{K}_{2} \mathrm{HPO}_{4}, 0.64 \mathrm{~g} ; \mathrm{KH}_{2} \mathrm{PO}_{4}, 0.30 \mathrm{~g} ; \mathrm{KNO}_{3}, 0.505 \mathrm{~g} ; \mathrm{Ca}\left(\mathrm{NO}_{3}\right)_{2} .4 \mathrm{H}_{2} \mathrm{O}$, $0.355 \mathrm{~g} ; \mathrm{NaNO}_{3}, 0.17 \mathrm{~g} ; \mathrm{MgSO}_{4} .7 \mathrm{H}_{2} \mathrm{O}, 0.37 \mathrm{~g}$; ferric EDTA, $3.5 \mathrm{mg} ; \mathrm{H}_{3} \mathrm{BO}_{3}, 0.57 \mathrm{mg} ; \mathrm{KCl}, 0.105$ $\mathrm{mg} ; \mathrm{MnSO}_{4}, 0.081 \mathrm{mg} ; \mathrm{CuSO}_{4} .7 \mathrm{H}_{2} \mathrm{O}, 0.04 \mathrm{mg} ; \mathrm{ZnSO}_{4} .7 \mathrm{H}_{2} \mathrm{O}, 0.022 \mathrm{mg} ;\left(\mathrm{NH}_{4}\right)_{6} \mathrm{Mo}_{7} \mathrm{O}_{24} .4 \mathrm{H}_{2} \mathrm{O}, 0.002 \mathrm{mg}$. For both media, the mineral salts and phosphate buffer (at $\times 10$ concentration) and the bulk of the medium including sucrose were autoclaved separately and mixed when cool.

Batch cultures were inoculated by sterile loop from agar slopes and grown for $14 \mathrm{~d}$ in $250 \mathrm{ml}$ conical flasks containing $100 \mathrm{ml}$ medium on a rotary shaker $\left(160 \mathrm{rev} \cdot \mathrm{min}^{-1}\right)$ at $25^{\circ} \mathrm{C}$. Continuous cultures $(D=0.01$ $\mathrm{h}^{-1}$ ) were inoculated with a $2 \mathrm{~d}$-old flask batch culture and grown in a chemostat (working volume $2.5 \mathrm{l}$ ) at $20^{\circ} \mathrm{C}, \mathrm{pH} 7.0$ and an oxygen partial pressure of $0.6 \mathrm{~atm}(60 \mathrm{kPa})$.

Seed inoculation. Complete cultures of $A$. chroococcum were normally used as inocula. For some experiments, however, cultures were centrifuged at $2000 \mathrm{~g}$ for $30 \mathrm{~min}$, and then the supernatant was passed through a membrane filter $(0.22 \mu \mathrm{m})$ and the centrifuged cells were resuspended in sterile medium without sucrose, centrifuged and again resuspended; the filtered supernatant and washed cell suspensions were used as inocula.

Barley seed (Hordeum vulgare) was soaked in the inoculum for $4 \mathrm{~h}$, during which time each seed imbibed $0.28 \mathrm{~g}$ water. For each treatment 30 seeds were added to $30 \mathrm{ml}$ inoculum at the temperature used for subsequent germination and seedling growth. Seeds were planted immediately after inoculation. Controls were treated in sterile medium without sucrose or in water.

Viable cell numbers in inocula were determined by conventional dilution plate counts on both media solidified with $1.5 \%(\mathrm{w} / \mathrm{v})$ agar. Plates were incubated at $25^{\circ} \mathrm{C}$ for $5 \mathrm{~d}$. Viable numbers on inoculated seed were determined after shaking 30 seeds in $50 \mathrm{ml}$ sterile $0.05 \%$ Manoxol OT (Hopkin \& Williams, Chadwell Heath, Essex) for $5 \mathrm{~min}$.

Seed germination in Petri dishes. For each treatment 30 seeds were planted into $15 \mathrm{~cm}$ diam. sterile glass Petri dishes. Each dish contained 10 seeds and either (i) a sterile filter paper pad $(11 \mathrm{~cm})$ moistened with the nitrate-containing medium without sucrose $(50 \mathrm{ml})$ or (ii) dry sterilized coarse sand $(1.0$ to $1.5 \mathrm{~mm}, 200 \mathrm{~g})$ moistened with nitrate-containing medium without sucrose $(45 \mathrm{ml})$. Dishes were incubated in the dark, and the percentage germination was recorded after $24 \mathrm{~h}$ and at the completion of the experiment, i.e. $120 \mathrm{~h}$ $\left(20^{\circ} \mathrm{C}\right), 168 \mathrm{~h}\left(15^{\circ} \mathrm{C}\right)$ or $288 \mathrm{~h}\left(10^{\circ} \mathrm{C}\right)$, when coleoptile and root lengths were also measured for each seedling.

Seed germination in flasks. Seed was planted on to dry sterilized coarse sand $(1.0$ to $1.5 \mathrm{~mm}, 1 \mathrm{~kg}$ ) moistened with sterile nitrate-containing medium without sucrose $(225 \mathrm{ml})$ in 21 conical flasks. Each flask contained 30 seeds and comprised one treatment. Oxygen concentrations were maintained at $21,10,5$ or $2.5 \%(\mathrm{v} / \mathrm{v})$ in flasks by continuously passing air or mixtures of air and nitrogen at $100 \mathrm{ml} \mathrm{min}^{-1}$; at concentrations of $10 \%$ or less the gas mixture was passed for at least $4 \mathrm{~h}$ before planting. Each day the flasks were weighed and evaporation losses were made up by addition of sterile distilled water, and oxygen concentrations were checked by gas chromatography (Smith \& Dowdell, 1973). Flasks were incubated in the dark and the percentage germination was recorded daily. Treatments in air were harvested after $120 \mathrm{~h}$. At lower oxygen concentrations when seedling growth was reduced, experiments were terminated when seedlings in the uninoculated control treatments had reached the same size as the controls in air. Coleoptile and root lengths were determined for each seedling.

Respirometer studies. Barley seed was inoculated with $5 \mathrm{~d}$-old flask cultures of $A$. chroococcum and planted on acid-washed, dry sterilized coarse sand $(1.0$ to $1.5 \mathrm{~mm}, 10 \mathrm{~g})$ moistened with sterile medium without 
Table 1. Root extension of barley seedlings at $20^{\circ} \mathrm{C}$ on filter paper after treatment of the seed with Azotobacter chroococcum grown in different media

\begin{abstract}
Azotobacter chroococcum was grown in flask cultures in nitrogen-free medium or nitrate-containing medium; seeds were treated with the complete culture or with culture separated as described in Methods. Control seeds were treated with sterile medium without sucrose.
\end{abstract}

\begin{tabular}{|c|c|c|c|}
\hline \multirow[b]{2}{*}{ Treatment } & \multirow[b]{2}{*}{ Dilution } & \multicolumn{2}{|c|}{$\begin{array}{l}\text { Root extension after } 5 \mathrm{~d} \\
\text { (\% of control) }\end{array}$} \\
\hline & & $\begin{array}{l}\mathrm{N} \text {-free } \\
\text { medium }\end{array}$ & $\begin{array}{l}\mathrm{NO}_{3}^{-} \text {-contain- } \\
\text { ing medium }\end{array}$ \\
\hline Complete culture & $\begin{array}{c}\text { Undiluted } \\
1 / 5 \\
1 / 50\end{array}$ & $\begin{array}{l}111 \\
133 \\
137\end{array}$ & $\begin{array}{l}49 \\
64 \\
70\end{array}$ \\
\hline Culture filtrate & $\begin{array}{c}\text { Undiluted } \\
1 / 5 \\
1 / 50\end{array}$ & $\begin{array}{r}94 \\
113 \\
117\end{array}$ & $\begin{array}{l}95 \\
95 \\
90\end{array}$ \\
\hline Cell suspension & $\begin{array}{c}\text { Undiluted } \\
1 / 5 \\
1 / 50\end{array}$ & $\begin{array}{l}129 \\
150 \\
154\end{array}$ & $\begin{array}{l}64 \\
57 \\
70\end{array}$ \\
\hline Least significant di & $0.05)$ & 19 & 15 \\
\hline
\end{tabular}

sucrose $(2.3 \mathrm{ml})$ in Gilson respirometer flasks cleaned in chromic acid. Each flask contained 10 seeds, planted embryo side uppermost, with four flasks in each treatment. Carbon dioxide was absorbed by $10 \%(\mathrm{w} / \mathrm{v})$ $\mathrm{KOH}(0.2 \mathrm{ml})$ with a filter paper 'wick' in the centre well. Oxygen uptake at $20^{\circ} \mathrm{C}$ was followed for $24 \mathrm{~h}$; $30 \mathrm{~min}$ were allowed for equilibration before the first reading and readings were then taken at 30 min intervals. A 'thermoblank' flask was included in all experiments to allow correction for changes in ambient temperature (Carver \& Gloyne, 1971). The percentage germination was recorded in each flask at hourly intervals between 15 and $24 \mathrm{~h}$.

\title{
RESULTS
}

The effect of $A$. chroococcum which had been grown in flask cultures on the root extension of barley seedlings is shown in Table 1 . Inoculation did not affect the percentage of seeds which germinated but root extension was stimulated by all types of inoculum preparation when the bacteria had grown in the nitrogen-free medium, except for the undiluted complete culture and undiluted culture filtrate. The stimulatory effects of inoculum type were in the order: cell suspension $>$ complete culture $>$ culture filtrate, but stimulation always increased progressively with dilution. In contrast, when seed was inoculated with undiluted complete cultures or suspensions of the bacteria grown in the medium containing nitrate, germination was reduced to 57 and $73 \%$, respectively; this effect was less marked when the medium was diluted. Culture filtrates of the nitrate-grown cells had no significant effect. Thus inhibition involves bacterial cells whereas stimulation involves, at least in part, metabolic products.

Seed was treated with IAA and $\mathrm{GA}_{3}$ to investigate whether these growth regulators were involved in the stimulation of root extension by cultures grown on the nitrogen-free medium (Fig. 1). Root extension was stimulated only by $10^{-4} \mathrm{M}_{-} \mathrm{GA}_{3}$ when added to the sand, a concentration higher than any that have been reported in cultures of $A$. chroococcum, and the stimulation was smaller than that observed with inocula from the nitrogen-free medium. Although IAA inhibited root growth of seedlings at the higher concentrations, this substance did not greatly inhibit the percentage germination. No synergistic effects were observed when IAA and $\mathrm{GA}_{3}$ were added together. There is no evidence, therefore, that the stimulation of seedling development or inhibition of germination when barley seed was inoculated with $A$. chroococcum could be attributed to IAA or $\mathrm{GA}_{3}$.

When complete culture inocula from the nitrogen-free medium were compared at different 


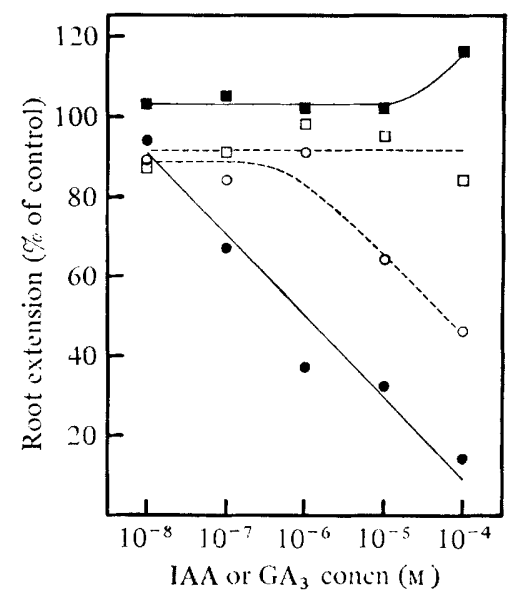

Fig. 1

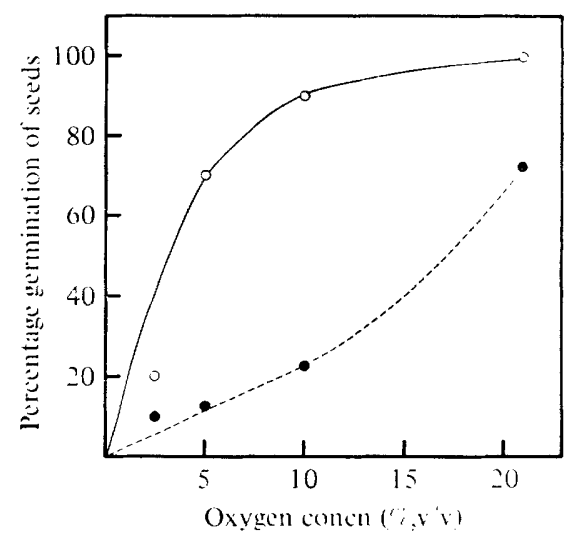

Fig. 2

Fig. 1. Root development of barley seedlings on moistened sand at $20^{\circ} \mathrm{C}$ after treatment of seeds with 3-indoleacetic acid, IAA (O) or gibberellic acid, $\mathrm{GA}_{3}(\square)$, or addition of IAA (C) or $\mathrm{GA}_{3}(\boldsymbol{\square})$ to the sand. No growth regulators were added to control seeds.

Fig. 2. Effect of Azotobacter chroococcum grown in nitrate-containing medium on the germination of barley seeds at $20^{\circ} \mathrm{C}$ in different concentrations of oxygen: $\bullet$, A. chroococcum; $\bigcirc$, control.

temperatures (Table 2), stimulation of root extension was observed at 10 and $15^{\circ} \mathrm{C}$ but not at $20{ }^{\circ} \mathrm{C}$. The inhibitory effects of the inocula from the nitrate-containing medium also varied with temperature and were reduced at the lower temperatures.

The effect of oxygen on the inhibition of germination by the cultures from the nitratecontaining medium is shown in Fig. 2. At oxygen concentrations of around $10 \%$, the inhibitory effect of the bacteria was increased, even though untreated seeds germinated normally.

The effects of oxygen and temperature on the bacterial action on barley are both in accord with the view that competition for oxygen between the bacterium and seed is involved in the inhibition. This hypothesis was tested by measuring the combined oxygen uptake of the seed and inoculum in a Gilson respirometer (Fig. 3). The oxygen uptake by seed inoculated with the inhibitory culture was initially higher than that of controls or of seed inoculated with the stimulatory culture, but there was no increase in oxygen uptake at the time when seed in non-inhibitory treatments was germinating. This result supports the hypothesis that germination is inhibited because of competition between the seed and inoculum for oxygen.

There was no consistent difference in the bacterial effects between seeds which were germinated on filter paper or sand. The inhibitory effects of cultures from the nitratecontaining medium were always observed whether cultures were derived from flasks or the chemostat. However, the stimulatory effects of the flask cultures from the nitrogen-free medium were not always observed. Attempts to achieve reproducibility by using steadystate chemostat cultures at different growth rates $\left(0 \cdot 1\right.$ to $\left.0.02 \mathrm{~h}^{-1}\right)$ and by ageing the cells at the completion of active growth were unsuccessful.

Whereas the specific growth rates of $A$. chroococcum on the different media were similar (Fig. 4), the $\mathrm{pH}$ of the medium without added nitrogen decreased rapidly. This resulted in a reduction of culture viability and within $120 \mathrm{~h}$ no viable cells could be detected. In contrast, the $\mathrm{pH}$ of the medium with nitrate and the cell viability $\left(2 \cdot 4 \times 10^{8}\right.$ viable cells $\mathrm{ml}^{-1}$ ) remained constant for at least $20 \mathrm{~d}$. This provides further evidence that active cells are involved in the inhibitory action but that metabolites are involved in the stimulation. 
Table 2. Seed germination and root extension of barley on sand after treatment of the seed with complete cultures of Azotobacter chroococcum grown in different media

Inocula were from flask cultures grown in media containing nitrate $\left(\mathrm{NO}_{3}{ }^{-}\right)$or free of nitrogen

( $\mathrm{N}$-free). Control seeds were untreated.

\begin{tabular}{|c|c|c|c|c|c|}
\hline \multirow{2}{*}{$\begin{array}{c}\text { Temp- } \\
\text { erature }\left({ }^{\circ} \mathrm{C}\right)\end{array}$} & \multirow{2}{*}{$\begin{array}{c}\text { Duration } \\
\text { of } \\
\text { assay (h) }\end{array}$} & \multirow{2}{*}{$\begin{array}{l}\text { Inoculum } \\
\text { growth } \\
\text { medium }\end{array}$} & \multicolumn{2}{|c|}{$\begin{array}{l}\text { Percentage } \\
\text { germination }\end{array}$} & \multirow{2}{*}{$\begin{array}{l}\text { Root } \\
\text { extension } \\
(\% \text { of } \\
\text { control })\end{array}$} \\
\hline & & & At $24 \mathrm{~h}$ & Final & \\
\hline 20 & 120 & $\begin{array}{l}\mathrm{N} \text {-free } \\
\mathrm{NO}_{3}^{-} \\
\text {Control }\end{array}$ & $\begin{array}{r}80 \\
0 \\
80\end{array}$ & $\begin{array}{r}100 \\
13 \\
97\end{array}$ & $\begin{array}{r}88 \\
52 \\
100\end{array}$ \\
\hline 15 & 168 & $\begin{array}{l}\mathrm{N} \text {-free } \\
\mathrm{NO}_{3}^{-} \\
\text {Control }\end{array}$ & $\begin{array}{r}70 \\
7 \\
70\end{array}$ & $\begin{array}{l}97 \\
33 \\
97\end{array}$ & $\begin{array}{r}132 \\
94 \\
100\end{array}$ \\
\hline 10 & 288 & $\begin{array}{l}\mathrm{N}-\text { free } \\
\mathrm{NO}_{3}^{-} \\
\text {Control }\end{array}$ & $\begin{array}{r}10 \\
0 \\
10\end{array}$ & $\begin{array}{l}93 \\
83 \\
90\end{array}$ & $\begin{array}{r}137 \\
97 \\
100\end{array}$ \\
\hline
\end{tabular}

* The least significant difference $(P=0.05)$ is 18 .

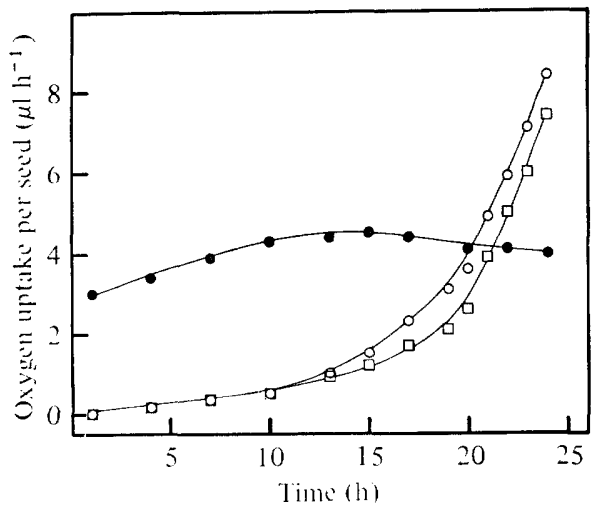

Fig. 3

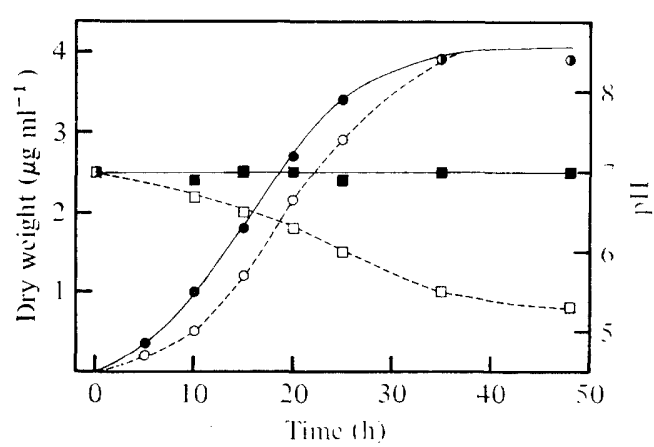

Fig. 4

Fig. 3. Oxygen uptake by barley seed inoculated with flask batch cultures of Azotobacter chroococcum. Seeds were planted on to sand in Gilson respirometer flasks at $20^{\circ} \mathrm{C}$. $\bigcirc$, Culture grown in nitrogen-free medium: $\bullet$, culture grown in nitrate-containing medium; $\square$, control.

Fig. 4. Growth of Azotobacter chroococcum and pH changes in the culture media of flask batch cultures at $25^{\circ} \mathrm{C}$. Nitrogen-free medium: $\bigcirc$, dry weight; $\square, \mathrm{pH}$. Nitrate-containing medium: $\bullet$, dry weight; $\mathbf{\square}, \mathrm{pH}$.

\section{DISCUSSION}

Cultures of $A$. chroococcum grown on nitrogen-free medium, which has been used conventionally in inoculation studies, stimulated seedling development but the stimulation was not consistently reproducible. Metabolic products of the inoculum appeared to be involved in the stimulation, although the presence of cells of $A$. chroococcum increased the effect. The stimulatory effects can therefore be ascribed to metabolites produced during culture of the inoculum without the necessity for seedling colonization by the inoculant. The failure to repeat the stimulation consistently prevented a fuller investigation of the mode of action. The involvement of specific plant growth regulators was not established and stimulation could not be brought about by IAA or $\mathrm{GA}_{3}$ at the concentrations which have been detected in bacterial cultures. Similar results were obtained when these growth regulators were applied to the roots of gnotobiotic barley plants (Lynch \& White, 1977). However, the possibility 
remains that other growth regulators, such as cytokinins which are produced by Azotobacter spp. (Lynch, 1979), or complex mixtures of metabolites may be involved.

Lynch \& White (1977) considered that the beneficial effects of $A$. chroococcum might be explained as the successful competition of the bacterium with antagonists of plant growth. In the present study, there was no evidence for the presence of antagonists but this remains a possible explanation for the stimulatory effects found in field experiments. It has also been shown that $A$. chroococcum can metabolize acetic acid (A. D. Rovira, personal communication), which is a phytotoxin in soils containing plant residues (Lynch, 1977), but the strain used in our experiments did not utilize acetate as a carbon source.

The cultures grown on the nitrate-containing medium were inhibitory only when cells were present, and inocula contained much higher numbers of viable cells than when cultured on the nitrogen-free medium. The observations that inhibition is increased at lower oxygen concentrations and that inhibitory cultures increase the combined rate of uptake by the seed and inoculum, support the hypothesis that competition for oxygen is involved in the inhibition of germination. Similar observations with a fungal inoculant (Lynch \& Pryn, 1977) suggest that microbial inocula which contain viable cells can, in general, compete with the seed for oxygen and prevent germination. This imposes a limitation on the number of viable cells that can be inoculated on to seeds without adverse effect. Large inocula have normally been used for field trials since colonization of the rhizosphere has been regarded as a prerequisite for increased seedling development.

Seed inoculation with micro-organisms remains a potential method for the promotion of satisfactory seedling emergence. This is an important stage in crop development and essential to achieve optimal plant populations and, in turn, maximum yield. However, since we could not consistently produce stimulatory inocula and as some inocula were inhibitory, there seem few prospects for the adoption of seed inoculation with $A$. chroococcum as a widescale agricultural practice.

The advice given by Dr P. J. Harris is gratefully acknowledged. Dr M. E. Brown'supplied the bacterial culture.

\section{REFERENCES}

BARbER, D. A. \& LYNCH, J. M. (1977). Microbial growth in the rhizosphere. Soil Biology and Biochemistry 9, 305-308.

BraKel, J. \& Hilger, F. (1965). Etude qualitative et quantitative de la synthèse de substances de nature auxinique par Azotobacter chroococcum in vitro. Bulletin de l'Institut agronomique et des stations de recherches de Gembloux 33, 469-487.

Brown, M. E. (1974). Seed and root bacterisation. Annual Review of Phytopathology 12, 181-197.

Brown, M. E., Burlingham, S. K. \& JaCKson, R. M. (1962). Studies on Azotobacter species in soil. II. Populations of Azotobacter in rhizosphere and effects of artificial inoculation. Plant and Soil 17, 320-332.

Carver, M. F. F. \& Gloyne, A. R. (1971). The effects of variations in ambient temperature on the Gilson differential respirometer. Laboratory Practice 20, 423.

CoOPER, R. (1959). Bacterial fertilizers in the Soviet Union. Soils and Fertilizers 22, 327-333.

Dalton, H. \& Postgate, J. R. (1969). Effect of oxygen on growth of Azotobacter chroococcum in batch and continuous culture. Journal of General Microbiology 54, 463-473.

LYNCH, J. M. (1977). Phytotoxicity of acetic acid produced in the anaerobic decomposition of wheat straw. Journal of Applied Bacteriology 42, 81-87.

LYNCH, J. M. (1979). Plant growth regulators. In Handbook of Microbiology, vol. VII, 2nd edn (in the Press). Edited by A. I. Laskin \& H. A. Lechevalier. Cleveland, Ohio: C.R.C. Press.

LYNCH, J. M. \& PRYN, S. J. (1977). Interaction between a soil fungus and barley seed. Journal of General Microbiology 103, 193-196.

LYNCH, J. M. \& WhITE, N. (1977). Effects of some non-pathogenic micro-organisms on the growth of gnotobiotic barley plants. Plant and Soil 47, 161-170.

MACLEOD, A. M. (1969). The utilisation of cereal seed reserves. Science Progress 57, 99-112.

Mishustin, E. N. (1970). The importance of nonsymbiotic micro-organisms in agriculture. Plant and Soil 32, 545-554.

Mishustin, E. H. \& Shilnikova, U. K. (1969). Free-living nitrogen-fixing bacteria of the genus Azotobacter. In Soil Biology, pp. 72-109. Paris: U.N.E.S.C.O.

Patel, J. J. (1969). Micro-organisms in the rhizosphere of plants inoculated with Azotobacter chroococcum. Plant and Soil 31, 209-223.

Postgate, J. R. (1974). New advances and future 
potential in biological nitrogen fixation. Journal of Applied Bacteriology 37, 185-202.

Rovira, A. D. (1965). Effects of Azotobacter, Bacillus and Clostridium on the growth of wheat. In Plant Microbes Relationships, pp. 193-200. Edited by J. Macura \& V. Vancura. Prague: Czechoslovak Academy of Sciences.

RÜBENCHIK, L. I. (1963). Azotobacter and its use in agriculture. Jerusalem: Israeli Program for Scientific Translations.
SiEgel, O. \& SchmidT, H. L. (1966). Laborversuche und Feldversuchsergebnisse mit AzotobacterImpfung. Landwirtschaftliche Forschung 19, 18-28.

Smith, K. A. \& Dowdell, R. J. (1973). Gas chromatographic analysis of the soil atmosphere: automatic analysis of gas samples for $\mathrm{O}_{2}, \mathrm{~N}_{2}, \mathrm{Ar}$, $\mathrm{CO}_{2}, \mathrm{~N}_{2} \mathrm{O}$ and $\mathrm{C}_{1}-\mathrm{C}_{4}$ hydrocarbons. Journal of Chromatographic Science 11, 655-658.

VANCURA, V. (1961). Detection of gibberellic acid in Azotobacter cultures. Nature, London 192, 88-89. 